\title{
Chimeric Antigen Receptor T-Cell Therapy: What the Neuroradiologist Needs to Know
}

\author{
(D) H.A. Valand, DF. Huda, and (D)R.K. Tu
}

\begin{abstract}
SUMMARY: Chimeric antigen receptor T-cell therapy is an exciting and rapidly emerging "fifth pillar" treatment for hematologic cancers. Unique treatment-related toxicities and cost remain a major hindrance to its widespread application. The commonly faced challenges with this innovative therapy, its neurotoxicity, and manifestation on neuroimaging studies, are reviewed.
\end{abstract}

ABBREVIATIONS: CAR $=$ chimeric antigen receptor; $C R S=$ cytokine release syndrome; CRES = CAR-T-cell-related encephalopathy syndrome

WHAT ARE CHIMERIC ANTIGEN RECEPTOR T-CELLS?

Two major types of immunotherapies have been developed during the past decade; 1) monoclonal antibodies agents specific to target tumor, and 2) adoptive $\mathrm{T}$-cell therapy, agents that mount an immune response against tumor cells. Chimeric antigen receptor (CAR) T-cells are the adoptive T-cell therapy agents that are genetically engineered to produce an immune response against tumor cells. ${ }^{1,2}$

\section{WHO BENEFITS FROM CAR T-CELL THERAPY?}

Since 2017, the US Food and Drug Administration has approved 2 CAR T-cell agents for 3 indications: 1) axicabtagene ciloleucel for relapsed/refractory diffuse large B-cell lymphoma, 2) tisagenlecleucel for pediatric and young adult leukemia, and 3) tisagenlecleucel for adult non-Hodgkin lymphoma. These therapies target, bind, and destroy cluster of differentiation 19 antigen, predominantly found in B-cell tumors. ${ }^{3-6}$

\section{HOW IS CAR T-CELL THERAPY DELIVERED TO PATIENTS?}

Manufacturing of CAR T-cells involves 5 phases: 1) extraction of T-cells with an apheresis technique; 2) reprogramming of T-cells by disarmed virus vectors, which genetically modify T-cells to

\section{Received February 17, 2019; accepted after revision March 6}

From the American University of Integrative Sciences (H.A.V.), Brampton, Ontario, Canada; Department of Radiology (F.H.), George Washington University Hospital, Washington, DC; and Progressive Radiology (R.K.T.), George Washington University, Washington, DC

Please address correspondence to Raymond K. Tu, MD, MS, FACR, Progressive Radiology, George Washington University, United Medical Center, 2121 K St NW,

Suite 100, Washington, DC 20037; e-mail: Raymond.Tu@progressiveradiology.net; @RayTu10

http://dx.doi.org/10.3174/ajnr.A6042 produce artificial protein receptors called chimeric antigen receptors, used to locate and bind the targeted tumor; 3 ) expansion and mass production of CAR T-cells and freezing when sufficient numbers are produced; 4) lymphodepletion, a reduction of the white blood cell load, making space for incoming reprogrammed CAR T-cells; and 5) infusion/treatment with CAR T-cells, in which cells multiply and mount an immune response against the targeted cancer cells. According to the current guidelines, patients are required to stay in the hospital from a few days to several weeks depending on their adverse effects profile. Posttreatment recovery time is approximately $2-3$ months. ${ }^{7-10}$

\section{WHAT ARE THE MAJOR TOXICITIES OF CAR T-CELL THERAPY AND HOW ARE THEY GRADED?}

Cytokine release syndrome (CRS) is the most commonly occurring toxicity in patients receiving CAR T-cell therapy followed by CAR-T-cell-related encephalopathy syndrome (CRES).

CRS results from immune activation resulting in elevated inflammatory cytokines. CRS-associated symptoms can range from fever, malaise, anorexia, and myalgias to end-organ dysfunction. There are 4 grades of CRS toxicity. Grade 1 comprises constitutional symptoms. Grade 2 includes hypotension that responds to fluids or low-dose vasopressors, hypoxia that responds to $<40 \%$ $\mathrm{O}_{2}$, and grade 2 organ toxicities. Grade 3 encompasses hypotension requiring high-dose vasopressors, hypoxia requiring $>40 \%$ $\mathrm{O}_{2}$, and grades 3 and 4 organ toxicities. Grade 4 also includes hypoxia requiring mechanical ventilation and grade 4 organ toxicities. ${ }^{1,12}$ Severe CRS toxicity can rarely progress into fulminant hemophagocytic lymphohistiocytosis. ${ }^{12}$

CRES-associated symptoms can range from mild neurotoxicity to more severe forms such as seizures, paralysis, raised intracranial pressure (ICP), papilledema, and cerebral edema. CRES is 
categorized into 4 grades based on neurologic assessment (orientation, naming of objects, ability to write a standard sentence, and counting backwards), raised ICP, and the presence of seizures or motor weakness. Grading of neurologic assessment is as follows: mild (grade 1), moderate (grade 2), severe (grade 3), and critical/ obtunded (grade 4 ). The presence of raised ICP, seizures, or motor weakness comprise grades 3 and $4 .^{13-15}$

A study conducted by Gofshteyn et $\mathrm{al}^{16}$ concluded that the incidence of neurotoxicity in pediatric and young adult populations $(\sim 45 \%)$ is similar to that found in the adult population ( $\sim 40 \%-42 \%)$. The study demonstrated that the occurrence of life-threatening neurotoxicity was lower in comparison with adults and all patients had neurologic recovery with no fatal outcomes.

\section{WHAT ARE THE NEURORADIOLOGIC FINDINGS IN PATIENTS RECEIVING CAR T-CELL THERAPY?}

A study conducted by Davila et $\mathrm{al}^{17}$ at the National Institutes of Health showed that patients who underwent neuroimaging had unremarkable examination findings.

Santomasso et al ${ }^{13}$ described 2 forms of neurotoxicity: mild and severe. Mild neurotoxicity comprises delirium, tremor, and headaches. Severe neurotoxicity ranges among disorientation, loss of attention, partial-to-global aphasia, myoclonus, and seizures. All patients with mild neurotoxicity had unremarkable MR imaging findings of the brain. In addition, of the 14 patients with severe neurotoxicity, 9 patients also had unremarkable changes. Patients with positive MR imaging findings showed a nonspecific pattern of predominantly white matter involvement extending to the brain stem. These nonspecific changes can also be seen with migraines and chronic microvascular ischemia resulting from common conditions such as hypertension among others. ${ }^{18}$ Following symptom resolution, 2 of the remaining 5 patients with MR imaging-positive findings had reversal of the MR imaging changes.

\section{WHAT ARE THE NEURORADIOLOGIC RECOMMENDATIONS IN PATIENTS RECEIVING CAR T-CELL THERAPY?}

Given the wide range of nonspecific brain findings and etiologies, the authors suggest a baseline pretreatment MR imaging to document any treatment-related changes. Given their immunocompromised state, these patients are prone to infections, which can result in the release of septic emboli into the bloodstream. This can lead to cerebritis and could further progress to abscess, advocating the use of contrast-enhanced MR imaging. ${ }^{19}$

\section{WHAT ARE THE CHALLENGES IN IMPLEMENTING CAR T-CELL THERAPY?}

Despite its promising treatment response, health plan coverage and drug costs are barriers to access CAR T-cell therapy. Axicabtagene ciloleucel and tisagenlecleucel treatment costs are estimated at $\$ 373,000$ and $\$ 475,000$, respectively. ${ }^{20,21}$ The nondrug costs due to adverse effects, apheresis, and lymphodepletion therapy are not part of these drug regimens and can cost from $\$ 30,000$ to $\$ 56,000$. $^{22}$ In addition, the facility costs to process and produce the final product, along with the use of cell therapy experts are enormous; treatment delivery, risk assessment, and legal counseling teams are important, costly, and essential. ${ }^{23}$ Currently, CAR T-cell therapy is not approved for Medicare patients. However, recently the US Centers for Medicare and Medicaid Services has proposed comprehensive nationwide coverage for CAR T-cell therapy. ${ }^{24}$

\section{REFERENCES}

1. Sathyanarayanan V, Neelapu SS. Cancer immunotherapy: strategies for personalization and combinatorial approaches. Mol Oncol 2015; 9:2043-53 CrossRef Medline

2. Khalil DN, Smith EL, Brentjens RJ, et al. The future of cancer treatment: immunomodulation, CARs and combination immunotherapy. Nat Rev Clin Oncol 2016;13:273-90 CrossRef Medline

3. Ruella M, Xu J, Barrett DM, et al. Induction of resistance to chimeric antigen receptor $\mathrm{T}$ cell therapy by transduction of a single leukemic B cell. Nat Med 2018;24:1499-1503 CrossRef Medline

4. U.S. Food and Drug Administration. STN: BL 125646/0. https:// www.fda.gov/downloads/BiologicsBloodVaccines/CellularGene TherapyProducts/ApprovedProducts/UCM574106.pdf. Accessed January 30, 2019

5. U.S. Food and Drug Administration. BL 125646/76. https://www. fda.gov/downloads/BiologicsBloodVaccines/CellularGeneTherapy Products/ApprovedProducts/UCM606523.pdf. Accessed January 28, 2019

6. U.S. Food and Drug Administration. BL 125643/0 https://www. fda.gov/downloads/BiologicsBloodVaccines/CellularGeneTherapy Products/ApprovedProducts/UCM581259.pdf. Accessed January 28, 2019

7. Chemical \& Engineering News. Controlling CAR-T: How scientists plan to make the engineered $\mathrm{T}$ cell therapy safer, and work for more cancers. https://cen.acs.org/pharmaceuticals/oncology/ControllingCAR-T-scientists-plan/96/i19. Accessed February 5, 2019

8. Leukemia and Lymphoma Society. Chimeric Antigen Receptor (CAR) T-Cell Therapy. https://www.lls.org/treatment/types-of-treatment/immunotherapy/chimeric-antigen-receptor-car-t-cell-therapy. Accessed February 6, 2019

9. National Cancer Institute. NCI Dictionary of Cancer Terms. https:// www.cancer.gov/publications/dictionaries/cancer-terms/def/cart-cell-therapy. Accessed February 6, 2019

10. Dana Farber Cancer Institute. How CAR T-cell works. https:// www.dana-farber.org/cellular-therapies-program/car-tcell-therapy/how-car-t-cell-therapy-works/. Accessed February 6, 2019

11. Lee DW, Gardner R, Porter DL, et al. Current concepts in the diagnosis and management of cytokine release syndrome. Blood 2014; 124:188-95 CrossRef Medline

12. Neelapu SS, Tummala S, Kebriaei $P$, et al. Chimeric antigen receptor T-cell therapy: assessment and management of toxicities. Nat Rev Clin Oncol 2018;15:47-62 CrossRef Medline

13. Santomasso BD, Park JH, Salloum D, et al. Clinical and biological correlates of neurotoxicity associated with CAR T-cell therapy in patients with B-cell acute lymphoblastic leukemia. Cancer Discov 2018;8:958-71 CrossRef Medline

14. Gust J, Hay KA, Hanafi LA, et al. Endothelial activation and bloodbrain barrier disruption in neurotoxicity after adoptive immunotherapy with CD19 CAR-T cells. Cancer Discov 2017;7:1404-19 CrossRef Medline

15. MD Anderson Cancer Center. Chimeric Antigen Receptor (CAR) Cell Therapy Toxicity Assessment and Management-Adult. https://www.mdanderson.org/documents/for-physicians/ algorithms/clinical-management/clin-management-cytokinerelease-web-algorithm.pdf. Accessed February 18, 2019

16. Gofshteyn JS, Shaw PA, Teachey DT, et al. Neurotoxicity after CTL019 in a pediatric and young adult cohort. Ann Neurol 2018;84: 537-46 CrossRef Medline

17. Davila ML, Riviere I, Wang X, et al. Efficacy and toxicity manage- 
ment of 19-28z CAR T cell therapy in B cell acute lymphoblastic leukemia. Sci Transl Med 2014;6:224ra25 CrossRef Medline

18. Trauninger A, Leél-Ossy E, Kamson DO, et al. Risk factors of migrainerelated brain white matter hyperintensities: an investigation of $186 \mathrm{pa}-$ tients. J Headache Pain 2011;12:97-103 CrossRef Medline

19. Smirniotopoulos JG, Murphy FM, Rushing EJ, et al. Patterns of contrast enhancement in the brain and meninges. Radiographics 2007; 27:525-51 CrossRef Medline

20. Lin JK, Lerman BJ, Barnes JI, et al. Cost effectiveness of chimeric antigen receptor $\mathrm{T}$-cell therapy in relapsed or refractory pediatric B-cell acute lymphoblastic leukemia. J Clin Oncol 2018 Sep 13. [Epub ahead of print] CrossRef Medline

21. Hao Y, Eldjerou LK, Yang H, et al. Cost-effectiveness analysis of CTL019 for the treatment of pediatric and young adult patients with relapsed or refractory B-cell acute lymphoblastic leukemia in the United States. In: Proceedings of the American Society of Hematology Annual Meeting and Exposition, Atlanta, Georgia. December 9-12, 2017; abstract 609

22. Hernandez I, Prasad V, Gellad WF. Total costs of chimeric antigen receptor T-cell immunotherapy. JAMA Oncol 2018;4:994-96 CrossRef Medline

23. Managed Health Care Executive. CAR T-cell therapy life-saving treatment, huge price tag. https://www.managedhealthcareexecutive.com/ sites/default/files/legacy/mm/digital/media/mhe1118_ezine_R1.pdf. Accessed February 6, 2019

24. Centers for Medicare \& Medicaid Services. Proposed Decision Memo for Chimeric Antigen Receptor (CAR) T-cell Therapy for Cancers (CAG00451N). Last Updated February 15, 2019. https://www.cms.gov/ medicare-coverage-database/details/nca-proposed-decision-memo. aspx?NCAId=291. Accessed February 15, 2019 